\title{
Exploring Recipients' Experience with the Home-based Rehabilitation Program Based on CBR Model through In-depth Interviews
}

\author{
Minyoung Lee', Jinjoo Chung², Hye Jung Hong ${ }^{3}$, Eunseung Kim³3 Bum Chul Yoon' \\ 'Department of Physical Therapy, College of Health Science, Korea University, Seoul; ${ }^{2}$ nnstitute for Society \& Health, Seoul; ${ }^{3}$ Jung-gu Public Health \\ Center, Seoul, Korea
}

Purpose: This study was conducted in order to explore self-perceived objectives, effects, determinant factors of satisfaction and demands on home-based rehabilitation service (HBRS) based on a community-based rehabilitation (CBR) model in community-dwelling disabilities. Methods: This research was conducted through in-depth interview. HBRS was conducted by four physical therapists for one hour a day, once a week, for eight weeks. After an eight-week intervention period, in-depth interviews were conducted using a semi-structured questionnaire for five recipients of HBRS and six care givers.

Results: For the physical effect, some participants experienced positive effects, whereas others did not due to the short-term intervention period. For the social and emotional effects, 'occurrence of motivation for exercise', 'change of surroundings' and 'sorriness for the therapist' emerged as keywords. For the determinant factors of satisfaction, 'movement-inducing therapy', 'therapy from the specialist', 'development of friendship \&t social network', and 'learning the way of self-rehabilitation' emerged as keywords. For further demands on HBRS, participants stated that 'sufficient time for therapy', 'user opinion-reflected therapy', 'additional instructions for therapeutic exercise \&t activities of daily living', and 'active promotion for HBRS' were necessary.

Conclusion: Participants were satisfied with the physical, social, emotional, and educational aspects of HBRS. In particular, the participants regarded educational aspects as the significant factor throughout self-perceived objectives, determinant factors of satisfaction and the demands. This result suggests that when providing HBRS to community-dwelling persons with disabilities, therapists should recognize the necessity and significance not only of the physical, but also the educational aspect of HBRS.

Keywords: Community-based rehabilitation, Home-based rehabilitation program, In-depth interview, Qualitative analysis

\section{서 론}

우리나라 총 장애인 수는 2011년 기준 2,683,477명으로 총 인구대비 $5.61 \%$ 에 달하며, 이는 2000년의 $1,449,496$ 명에 비해 $82 \%$ 가 증가한 수치 로 이들에 대한 적절한 의료와 재활서비스 제공이 절실히 필요한 실 정이다. 특히 이 중 지체장애와 뇌병변장애의 비율은 각각 총 인구 대비 $2.72 \%, 0.59 \%$ 를 차지하여 1,2 위를 차지하고 있다. 고령화의 급진 전과 함께 후천적 장애인의 증가를 염두에 둔다면 전체 대비 장애인 의 인구는 크게 증가할 것으로 예상된다. 하지만 장애인을 위한 의 료·재활서비스의 제공은 비장애인에 비해 크게 떨어진다. 비장애인 의 건강검진 수검률은 2011 년에 $72.82 \%$ 에 달하는 것에 비해, 장애인

Received March 24, 2015 Revised April 18, 2015

Accepted April 19, 2015

Corresponding author Bum Chul Yoon

E-mail yoonbc@korea.ac.kr
의 수검률은 지체장애인의 경우 $69.80 \%$, 뇌병변 장애인의 경우 $45.29 \%$ 에 그쳐, 장애인이 의료서비스 영역에서 상대적으로 소외되고 있음을 알 수 있다.1

장애인의 열악한 의료서비스 접근 기회는 이미 80년대부터 세계적 인 문제로 대두되어왔으며, 1981년에 세계보건기구(World Health Organization, $\mathrm{WHO}$ )는 이에 대한 대책으로 지역사회중심재활(Community-based rehabilitation, $\mathrm{CBR}$ )을 제안하였다. 초기 CBR활동은 일 차보건의료(primary health care)의 확장 개념으로 의학적 서비스 전달 로써의 의미가 강조되었으나, 최근에는 지역사회개발 개념으로 정의 가 변화되어 가고 있는 추세이다. 이에 따라 $\mathrm{CBR}$ 활동 모형은 장애인 의 기능적 능력 향상을 중시했던 '의학적 모형'에서, 장애인에게 동등 
한 기회를 제공하는 수용적인 사회 환경 조성, 장애인의 지역사회 참 여 등을 포함하는 사회적 모형으로 확장되었다. 뿐만 아니라, CBR활 동 초기에는 장애인의 역할이 수동적인 서비스 수혜자에 그쳤다면, 최근에는 적극적인 '사용자' 혹은 $\mathrm{CBR}$ 사업의 '결정권자로 변화되어 가고 있다. ${ }^{2}$

$\mathrm{CBR}$ 활동과 관련한 이와 같은 세계적 추세에 발맞추어 우리나라 보건복지부에서는 1995년에 최초로 서울 도봉구 보건소와 경기도 남양주시 보건소에서 $\mathrm{CBR}$ 사업을 시범적으로 실시하였고, 이후에도 일부 지역에서 CBR사업을 수행해왔다. 2013 년부터는 보건복지부에 서 주관하는 지역사회통합건강증진사업의 일환으로 $\mathrm{CBR}$ 사업을 시 행하기 시작하였으며, 이에 따라 전국에서 $\mathrm{CBR}$ 사업을 시행하는 거 점 보건소는 2013년에 88개소에 이르렀다. 특히 서울시의 경우 2013 년도에 총 25 개 구 중 6 개 구의 보건소(25\%)가, 그리고 2014년에는 12 개 구의 보건소(48\%)가 CBR사업을 시행하였고, 2017년까지는 25개 구에 속한 모든 보건소(100\%)가 CBR사업을 수행하는 것을 목표로 하고 있다. ${ }^{3}$

한편, 국립재활원에서 정의 내리고 있는 CBR사업 중점관리 대상 자는 "재가 장애인 중 건강관리, 재활훈련 등의 서비스를 지속적으로 필요로 하는 자”이고, 이와 같은 중점관리 대상자 중에서도 '저소득 층' 및 '재가중증장애인'을 우선순위 선정대상자로 정의하고 있다. 3 이와 같은 국립재활원의 대상자 선정기준에 따라, 국내에서는 저소 득층 재가장애인을 대상으로 한 방문재활사업이 중요한 $\mathrm{CBR}$ 활동 중 하나로 주목을 받아 왔다. 학계에서도 1990년대부터 현재까지 방 문재활사업에 대한 많은 연구가 진행되어왔다. 예를 들어, 국외 방문 재활 시스템 소개를 위한 문헌고찰-7, 방문재활서비스가 장애인의 신 체기능 향상에 미치는 효과분석-11 , 방문재활서비스 제공자(물리치 료사, 방문사업팀 등)가 인식하는 방문재활사업에 대한 필요성 12,13 등 에 관한 다수의 연구가 있다.

그러나, 방문재활대상자 관점에서 방문재활사업에 대한 인식과 경 험을 분석한 연구는 아직 매우 제한적으로, 방문재활서비스 수급 경 험이 없는 노인 혹은 장애인을 대상으로 방문재활서비스에 대한 인 식과 이용의사 등을 분석한 연구는 있으나 ${ }^{14-18}$, 실제 방문재활서비스 를 수급한 노인 혹은 장애인을 대상으로 진행된 연구는 $\mathrm{Ahn}$ 과 $\mathrm{Yu}^{19}$ 그리고 $\mathrm{Jng}^{17}$ 의 연구 이외에는 찾아보기 힘들다. 이는 아마도 지역사 회 차원의 방문재활의 역사가 짧고, 그에 따라 적용사례가 적기 때문 인 것으로 풀이된다.

한편, $\mathrm{Ahn}$ 과 $\mathrm{Yu}$ 의 연구 ${ }^{19}$ 는 방문재활사업의 참여한 환자 125 명을 대상으로 설문조사를 통해 방문재활서비스에 대한 만족도 및 만족 요인에 대해 분석하였으나, 설문조사를 이용한 양적 연구방법의 한 계로 인해 설문문항 이외의 만족요인이 방문재활대상자 관점에서 충 분히 도출되었다고 보기 힘들다. 또한 Jang의 연구17는 방문재활서비
스를 수급한 10 명의 환자에 대해 심층면담을 통해 방문재활서비스에 대한 요구도를 질적으로 분석하였으나, 심층면담을 위한 질문이 명 확하지 않고, 심층면담 결과에 대해 주제에 따른 범주화작업이 충분 히 수행되지 않아 설득력 있는 시사점 도출에는 제한이 있는 것으로 보인다.

세계적으로 $\mathrm{CBR}$ 활동에서 장애인의 역할이 수동적인 서비스 수혜 자에서 적극적인 사용자로 변화해 가는 추세임을 감안할 때, 방문재 활대상자 관점에서의 방문재활서비스에 대한 인식과 경험이 보다 심 도 깊게 분석될 필요가 있을 것으로 판단된다. 따라서 본 연구에서는 $\mathrm{CBR}$ 모형 기반의 방문재활서비스를 8 주간 수급한 장애인 혹은 그 보 호자가 주관적으로 경험하고 인식한 방문재활서비스의 목적, 효과, 만족도, 요구사항을 심층면담 기법을 이용하여 분석하고자 한다. 심 층면담 기법은 질적연구방법의 한 유형으로 연구자가 설정한 가설에 대한 연역적인 검증을 목적으로 하는 양적연구와는 달리, 연구자가 의도하는 가설이 없이 연구대상자의 주관적인 인식과 경험을 심층면 담을 통해 이끌어내고, 그 결과를 귀납적으로 분석하여, 주요한 범주 단위로 정리해 나가는 방법이다.20,21 이와 같은 연구결과는 향후 국가 기관 및 보건소에서 CBR모형에 기반한 방문재활사업을 계획하고 진 행하는데 방문재활대상자 관점에서 분석된 유용한 정보를 제시할 수 있을 것으로 사료된다.

\section{연구방법}

\section{1. 연구절차}

본 연구는 서울시 중구 보건소 주도 하에 진행된 된 2014년도 서울시 중구 지역사회통합건강증진사업 중 방문재활사업에 대해 방문재활 대상자 관점에서 평가하기 위해 진행되었다. 서울시 중구 보건소는 보건복지부와 국립재활원의 2013년 CBR사업 운영지침에 따라 보건 소 및 보건지소, 장애인복지관, 종합사회복지관, 데이케어센터, 장애 인자립생활센터, 구청 그리고 $\bigcirc$ ○대학교 소속의 전문가로 구성된 지 역사회재활협의체(이하 ‘협의체')를 결성하였다. 협의체는 총 세 차례 의 회의를 통해 방문물리치료사를 선정하고, 방문재활대상자 선정 기준 및 발굴방법, 그리고 방문재활활동 기간 및 횟수를 결정하였다. 선정된 방문물리치료사들은 협의체에서 결정한 방문재활대상자 선 정기준에 따라 대상자를 선정하고, 방문재활활동 시 적용할 구체적 인 중재방법을 결정하였다. 연구자들 방문물리치료사가 방문재활활 동을 종료 한 이후 방문재활대상자와 그 보호자가 주관적으로 인식 및 경험한 방문재활서비스의 목적, 효과, 만족도 및 요구사항에 대해 개별 심층면담(in-depth interview)을 진행하고, 그 결과를 질적연구방 법 20,21을 이용해 도출하였다. 이와 같이 방문재활대상자와 그 보호자 를 대상으로 수행하는 질적연구는 전문가 위주의 견해를 탈피하고, 
그들의 인식과 경험을 반영하여 방문재활사업의 효과성을 극대화하 기 위해서도 중요하다.

\section{2. 연구대상자}

총 10 명의 서울시 중구 거주 장애인에게 방문재활서비스가 제공되었 다. 그 중 방문재활에 대한 경험을 연구자에게 제공할 수 있을 정도의 의사소통 능력이 있는 5 명의 방문재활대상자와 의사소통이 불가능 한 방문재활대상자의 보호자(가족 및 활동보조사) 6 명이 본 연구에 참여하였다. 방문재활대상자의 장애유형은 중구에 등록된 총 장애 인(6,102명) 중 첫 번째( 3,154 명), 그리고 시각장애인에 이어 세 번째 (648명)로 높은 수를 차지하는 지체장애와 신경계 질환자로 제한하 였다. ${ }^{20}$ 연구대상자의 임의선정기준은 다음과 같다: (1) 장애인복지관 의 사회복지사가 선별한 자, (2) 종합사회복지관 방문재활팀이 선별한 자, (3) 보건지소 방문간호사가 선별한 자, (4) 장애인자립생활센터에 서 방문재활을 희망한 장애인. 본 연구는 모든 참여자들의 서명 동의 하에 진행되었고, $\bigcirc \bigcirc$ 대학교 윤리심의위원회의 심의를 득하였다 (KU-IRB-14-76-A-2).

\section{3. 방문재활서비스 제공시기 및 방법}

협의체의 결정에 따라 방문재활서비스를 위한 중재는 보건소, 보건 지소 및 종합사회복지관에 소속되어 있는 총 4 명의 물리치료사에 의 해, 2014년 5월부터 7월 사이에 회당 1시간, 주 1회, 총 8 주간 진행되었 다. 방문재활서비스 내용으로는 관절가동 운동, 근력운동, 통증치료, 자가 재활운동 교육 등이 방문재활대상자의 상태와 요구에 맞게 진 행되었다. 중구 보건소에서 4 명의 방문 물리치료사에게 근력운동을 위한 고무밴드와 통증치료를 위한 휴대용 경피신경자극치료기와 기 능적전기자극치료기를 지급하였다.

\section{4. 자료수집방법}

세 명의 연구원은 각각 담당 연구대상자를 대상으로 개별 심층면담 을 진행하였다. 심층면담은 연구대상자가 선호하는 시간에, 방문재 활대상자의 가택에서, 연구자와 연구대상자 간의 1:1 대면으로 수행 하는 것을 원칙으로 하였다. 다만 연구대상자가 방문재활대상자인 경우에는 방문재활대상자의 의사에 따라 보호자의 대동 하에 심층 면담을 진행할 수 있도록 하였고, 이때 연구자와 방문재활대상자 간 의 면담 도중, 보호자가 추가적으로 대답하는 것을 허용하고, 그 내용 도 분석 대상에 포함시켰다. 연구자는 연구대상자 1 인당 1 회에서 2 회 이상의 면담을 수행하였고, 회당 면담 시간은 1 시간 가량 소요되었 다. 모든 면담 내용은 연구대상자와의 동의 하에 녹취하였다.

심층면담은 연구자가 반구조화된 면담지를 사용하여 개방적 질 문을 하고, 연구대상자가 이에 대해 자유롭게 응답하는 형식으로 수
행되었다. 질문 주제는 다음과 같다: (1) "지난 8주간의 물리치료사가 방문하여 수행한 활동은 무엇을 위한 것이라고 생각하십니까?”, (2) "방문재활 활동을 통해 어떤 효과를 느끼셨습니까?”, (3) “방문재활에 대해 만족 혹은 불만족하신 부분이 있다면 그것은 무엇입니까?”, (4) "8주간 받으신 서비스 이외에 필요하다고 생각하시는 서비스가 있다 면 그것은 무엇입니까?”

\section{5. 자료분석}

세 명의 연구자들은 녹취한 면담내용을 모두 필사 하였으며, 필사자 료가 완성된 이후에는 모든 연구자가 각자 진술된 자료를 반복적으 로 읽어나가면서 탐색하고자 하는 현상과 관련된 부분에 밑줄을 그 어 가며, 의미 있는 진술을 도출하였다. 각자가 의미 있는 진술을 도 출 한 후에는 연구자들간의 논의를 통해 도출된 의미를 주제, 범주1, 범주2 단계로 분류 및 조직하는 작업을 거쳤다. 이 과정에서 연구자 들 사이에 타당성이 합의되지 않거나, 혹은 연구자들 간에 이견이 있 는 자료들은 다시 재분류 및 조직화하는 과정을 거쳐서 관심 있는 현 상에 대해 통합적으로 기술하고자 하였다. 마지막으로 분석결과의 타당도 검증을 위하여 연구대상자에게 분석된 자료를 설명하여 그 내용의 적절성을 확인하는 과정을 거쳤다. ${ }^{21}$ 본 연구에서 심층면담 및 자료 분석은 임상경력 10 년 이상의 물리치료학과 교수 1 인과 다년간 의 질적연구 경험을 가진 사회학 박사의 1 인의 지도 하에 진행되었다.

\section{결 과}

\section{1. 연구대상자 특성}

총 10 명의 방문재활대상자는 2 명의 지체장애인과 8 명의 신경계질환 장애인로 구성되었다. 7 명의 재활대상자는 연령대가 50 대 이상으로 높은 편이었으나, 한 명은 35 세, 두 명은 15 세 이하로 다양하게 구성되 어 있었다. 대부분의 재활대상자는 기초생활수급자이거나 혹은 수 급을 받지 못하더라도 경제적 어려움을 호소하고 있었다. 이들 중 5 명은 인지 및 언어구사 능력의 제한으로 직접 심층면담을 수행하기 어려워, 동거 중인 가족 혹은 활동보조사가 대신 심층면담을 수행하 였다(Table 1).

\section{2. 방문재활 서비스의 목적}

연구대상자들은 방문재활서비스의 목적에 대해 '신체기능 유지 및 개선을 위한 운동치료', 자가 재활운동 방법 교육', 그리고 '일상생활 수행지도' 등으로 다양하게 인식하고 있었다(Table 2).

1) 신체 기능 유지 및 개선을 위한 운동치료

연구대상자들은 질병이 있는 부위를 움직여 주지 않으면 관절이 굳 
Table 1. Sociodemographic and clinical characteristics of the participants

\begin{tabular}{|c|c|c|c|c|c|c|c|}
\hline $\mathrm{ID}^{*}$ & $\begin{array}{l}\text { Diseases of } \\
\text { recipient }\end{array}$ & $\begin{array}{l}\text { Sex of } \\
\text { recipent }\end{array}$ & $\begin{array}{l}\text { Age of } \\
\text { recipient } \\
\text { (year) }\end{array}$ & $\begin{array}{c}\text { Participant of } \\
\text { interview }\end{array}$ & $\begin{array}{l}\text { State of living } \\
\text { wih family }\end{array}$ & $\begin{array}{c}\text { Beneficiary of } \\
\text { NBL }\end{array}$ & Institute selecting recipient \\
\hline A & Physical disabilities & M & 76 & Recipient & - & - & Social worker in the social welfare center \\
\hline B & Physical disabilities & M & 35 & Care giver & Cohabitation & Beneficiary & Social worker in the social welfare center \\
\hline C & Spine injury & $\mathrm{F}$ & 79 & Recipient & - & Beneficiary & Social worker in the social welfare center \\
\hline D & Stoke & $\mathrm{F}$ & 77 & Recipient & - & - & HRBS team in the social welfare center \\
\hline E & Stoke & M & 83 & Care giver & Cohabitation & - & $\begin{array}{l}\text { Visiting nurse in the branch office of the community } \\
\text { health center }\end{array}$ \\
\hline $\mathrm{F}$ & Stoke & $\mathrm{F}$ & 79 & Recipient & - & - & $\begin{array}{l}\text { Visiting nurse in the branch office of the community } \\
\text { health center }\end{array}$ \\
\hline G & Poliomyelitis & $\mathrm{F}$ & 54 & Care giver & Cohabitation & - & $\begin{array}{l}\text { Visiting nurse in the branch office of the community } \\
\text { health center }\end{array}$ \\
\hline $\mathrm{H}$ & Spine injury & M & 56 & Recipient & Cohabitation & - & Applicant in the independent living center \\
\hline । & Cats cry syndrome & $\mathrm{F}$ & 14 & Care giver & Cohabitation & - & Applicant in the independent living center \\
\hline J & Cerebral palsy & M & 12 & Care giver & Cohabitation & - & Applicant in the independent living center \\
\hline
\end{tabular}

NBL, national basic livelihood; F, Female; M, Male.

* indicates the code of recipient; ' indicates the participants of in-depth interview for the study.

Table 2. Theme and categories of the participants' self-perceived objectives of the HRBS

\begin{tabular}{ll}
\hline Theme & \multicolumn{1}{c}{ Category } \\
\hline Self-perceived objectives of the HRBS & Therapeutic exercise for maintaining \& improving physical function \\
& Training of self-rehabilitation methods \\
& Instruction for activities of daily living \\
\hline
\end{tabular}

HRBS, home-based rehabilitation service.

는데, 그러한 문제를 방지하기 위한 운동을 시켜주는 것이 방문재활 서비스의 목적이라고 하였다. 또한, 혈액순환을 원활하게 하여 질병 으로 인해 동반되는 증상을 최소화하는 것이라고도 하였다.

"선생님은 이렇게 저렇게 하라고 맨날 가르치셔. 그냥 있으면 굳으 니까 그러지 말라는 거지. 이거(운동)를 안 하면 (관절이) 굳는단 말이 야..... 운동을 한다는 거는 더 이상 굳지 말라고" (재활대상자 F)

"운동치료라는 게 그게 뭐 막 되는 게(효과가 바로 나타나는 게) 아 니라고 생각해요. 더 굳지 않고 더 나빠지지 않기 위해서 꾸준히 관리 하는 데 목적이 있지..... 저 같은 경우에는 신경을 다쳐서, 이게 낫지 를 않는다는 거죠. 더 망가지지 않게, 쭉 관리하고 있는 게 중요하죠" (재활대상자 $\mathrm{H}$ )

"이렇게 하면(스트레칭) 여기(다리)가 다 땡겨요. 그거(스트레칭)를 쉬지 말고 (하라고). 이 다리가 쥐가 나서 못 살아요. 그럴 때 선생님이 항시 하는 말이 혈액순환이 안 되니까 움직이라고" (재활대상자 C)

\section{2) 자가 재활운동 방법 교육}

연구대상자들 중 일부는 방문재활은 질병을 근본적으로 낫게 하기
보다는, 질병으로 인한 구축이나 괴사를 혼자서 혹은 보호자의 도움 으로 지속적으로 관리할 수 있는 방법을 교육받기 위한 것으로 인식 하였다.

"나를 낫게 한다는 그런 거보다는, 현재 있는 활동보조인이나 가족 들에게 운동할 수 있는 법을 알려줘서 지속적으로 꾸준히 관리를 하 라는 의미에서 하지 않았나, 저는 그렇게 생각을 하고 있어요" (재활 대상자 $\mathrm{H})$

"그러니까 몸이 불편하니까 이 공치기, 나하고 둘이 받기..... 뭐 여 러 가지 해요..... 하나(공)는 날 보고 하라고, 주고 가더라고요" (재활 대상자E보호자)

\section{3) 일상생활 수행 지도}

방문물리치료사로부터 일상적인 활동들을 어떻게 수행해야 하는지 를 지도 받기 위한 활동으로 인식하고 있는 연구대상자도 있었다.

"이 동네에는 병원이 없어요. 그것 때문에 장애인 택시를 불러야 하는데, 휠체어로 움직이기에는 경사가 너무 심해서 아주 힘들더라 고요. 그래서 (병원에 갈 때) 아예 차나 택시를 이용해야 하는데, 선생 
님이 오셔서 어떻게 해야 하는지 그 방법을 가르쳐주니까" (재활대상 자 $\mathrm{B}$ 보호자)

"언제 약을 먹어야 하는지, 무 그런 거 알려주니까 좋죠... 또, 제가 혼자서 못하는 것... 파스 붙이는 거나.. 그런 것도 도와주니까 좋고 요" (재활대상자 $\mathrm{A}$ )

\section{3. 방문재활서비스의 효과, 만족요인, 요구사항}

연구대상자들은 방문재활서비스 수급으로 신체적 효과와 사회적. 감정적 효과도 경험하였다고 하였다. 만족요인으로는 치료적 요소와 사회적.감정적, 교육적 요소를 언급하였다. 향후 방문재활활동을 수 행함에 있어서는 치료적, 교육적, 행정적 요소에 대해 추가적인 보완 이 필요하다는 의견이 제시되었다. Table 3 은 방문재활서비스에 대한 효과, 만족요인, 요구사항에 대해 연구대상자들이 언급한 내용을 각 각의 주제별로 범주화하여 제시하고 있다.

\section{1) 방문재활서비스의 효과}

연구대상자들은 신체적 요소와 사회적-감정적 요소에서 방문재활 서비스의 효과를 경험하였다고 언급하였다.

\section{(1) 신체적 요소}

방문재활서비스 수급 이후 신체 기능이 유지되거나 개선되었다는 내 용이 있었다. 주된 신체적 효과는 관절가동범위의 증가였다.

"내가 보기에 (침대에서) 좀 편하게 일어나고, 편하게 앉고..... 팔
을 반도 못 돌렸는데, 인제 이 팔을 여기까지 좀 돌리더라고. (운동을) 팔하고 목을 집중적으로 하셨는데, 그러니까 팔을 조금 더 쓰더라고" (재활대상자 $\mathrm{G}$ 보호자)

"처음 운동 시작할 때부터 제 각도가 나오는 게 아니에요. 처음부 터 조금씩 조금씩 해서 관절을 풀어가야 제 각도가 나오거든요. (방 문재활서비스를) 받고 나서 좀 풀어지면 (관절이) 구부러질 수 있는 데까지 그 각도가 나오죠. 그러니까 받는 게 좋죠" (재활대상자 $\mathrm{H}$ )

"팔 들어올리는 게 조금 나아졌어. 예전에는 머리를 못 감았는데 이제는 머리를 감아" (재활대상자 C)

하지만 별다른 효과가 없다는 의견도 있었다. 효과가 없는 주된 원 인으로는 짧은 치료 기간을 꼽았다.

“제가 감각이 잘 없어서 '무지 효과 있다’ 이런 거는 못 느낀 것 같아 요. 받을 때 당시는 움직이는 각도가 더 나오다가 또 좀 지나면 그냥 원위치 되고 그러더라고요..... 아무래도 계속적으로 좀 풀어주고 해야 되는데......" (재활대상자 $\mathrm{H}$ )

"그 때(물리치료 받을 때)에는 효과가 있어도요, 그거를 길게 해야 지, 솔직히 8주 해 가지고는 안 되는 거거든. 좋아지는 속도가, 8주 했 다고 좋아지는 게 아니고, 그래서 애기 때부터 병원도 다니고 하는 거 니까. 그럴 것 같았으면 다 좋아졌지. 좋기는 한데, 좀 짧죠" (재활대상 자 J보호자)

Table 3. Themes and categories of the participants' self-perceived effects, determinant factors of satisfaction \& further demands on the HRBS

\begin{tabular}{|c|c|c|}
\hline Theme & Category 1 & Category 2 \\
\hline \multirow[t]{5}{*}{ Effects } & Therapeutic aspect & Maintaining \& improving physical function \\
\hline & & No effect \\
\hline & Social \& emotional aspects & Occurrence of motivation for exercise \\
\hline & & Change of surroundings \\
\hline & & Sorriness for the therapist \\
\hline \multirow[t]{5}{*}{ Determinant factors of satisfaction } & Therapeutic aspect & Movement-inducing therapy \\
\hline & & Therapy from the specialist \\
\hline & Social \& emotional aspects & Development of friendship \\
\hline & & Development of social network \\
\hline & Educational aspect & Learning the way of self-rehabilitation \\
\hline \multirow[t]{4}{*}{ Further demands } & Therapeutic aspect & Sufficient time for therapy \\
\hline & & User opinion-reflected therapy \\
\hline & Educational aspect & Additional instructions for therapeutic exercise \& activities of daily living \\
\hline & Administrative aspect & Active promotion for HBRS \\
\hline
\end{tabular}

HRBS, home-based rehabilitation service. 


\section{(2) 사회적·감정적 요소}

재활대상자들은 대부분 장기간 운동을 하지 않아 기능에 장애가 있 었고, 그와 같은 기능 장애가 개선될 여지가 없다고 생각하는 사람들 이었다. 이러한 대상자들에게 방문재활서비스는 운동을 해야 하는 동기를 제공하는 계기가 되었다. 운동을 계속하게 되는 주된 이유는 치료사에 대한 고마움이나 애정이었다.

"많이는 못 하지만 하도 고마워서...... 선생님이 발을 항시 가만히 있지 말고 움직이라고..... 어디에 좋은지는 몰라요. 근육이 당기잖 아요? 이것은 그냥 땡기라고 하는 운동인갑다 그러지. 자꾸 올렸다 내렸다 하라고..... 가르쳐준 것이 고마워서 해야지 하고 하게 되는 거지. 감사해서" (재활대상자 C)

"우리가 뭐 한다고 하면 되게 싫어하거든요. 근데 선생님이 해 주니 까 되게 좋아하더라고요. 좋아하고 잘 따라 하고...... 개도 익숙하니 까 더 편할 테고, 집이라서 아무래도 더 편할 테니까. 또 (집이라서) 개 가 원하는 걸 주면서 달래가면서 할 수도 있고, 집에 있으면 자기가 원 하는 걸 말하고" (재활대상자 J 보호자)

재활대상자들은 신체적 한계로 대부분의 시간을 집에서 가만히 보낸다. 주변 환경이 변하지 않아서 일상이 매우 단조롭고, 기분도 가 라앉은 채로 별다른 변화가 없다. 이들은 방문재활을 통해, 외부인이 방문한다는 그자체로 기분이 전환되는 느낌을 받았다.

"선생님이 오셔서 했는데, 진짜 자상하게 잘 해 주셔서...... 그래서 그런지, 사람이 좀 더 밝아진 것 같아요..... 사람을 상대해서 그런지. 자기가 좀 위안을 받았는지, 사람이 좀 더 밝아진 것 같아" (재활대상 자 $\mathrm{G}$ 보호자)

"아니, 그것(시켜주는 운동)도 못해. 단지 기분이 좀, 그거 하고 나면 좀 마음이 저거 한 거(좋아져). 일어나지를 못하니, 바깥에 나가보려 고 하면 못 나가니까" (재활대상자 F)

또한 연구대상자들은 무상으로 치료를 제공하는 치료사들에 대 해 미안한 마음을 가졌다. '나 같은 사람에게 이렇게까지 해 준다라 고 여겼고, 치료사의 요구대로 몸과 마음이 따라주지 않아서 미안하 다고 생각하고 있었다.

"하루를 가르쳐 주면 내가 그거를 맹신하고 실천을 해야 하는데 그 걸 내가 안 하면 어쩌겠어. 선생님한테 미안하고 고생만 시키고...... 실천을 못 해서 자꾸 미안해서 그려. 하려고 노력해야 하는데 (그렇지
가 않아서). 그런 것이 미안해서 그려" (재활대상자 C)

"뭐 그냥 너무나도 땀 흘리고 하시니까, 시간은 미안해서 더 요구도 못 하겠고" (재활대상자 $\mathrm{G}$ 보호자)

\section{2) 방문재활서비스에 대한 만족요인}

연구대상자들은 방문재활서비스에서 만족감을 느낀 요인으로 치료 적 요소와사회적 - 감정적 요소, 그리고 교육적 요소를 언급하였다.

\section{(1) 치료적 요소}

자발적으로 운동할 수 있는 환경과 의지를 갖추지 못하고 있는 대상 자들은, 장애가 즉시 개선되지 않더라도 치료사가 수동적 또는 능동 적으로 움직임을 일으켜 주는 것 자체에 대해 만족하고 있었다. 공인 된 자격이 없는 사람보다 전문성을 지닌 물리치료사가 직접 운동을 시켜주는 것에 대해 만족하는 대상자도 있었다.

"팔도 한번 해 보고, 다리도 뭐 해 보라고 해. 내가 피곤한 거 알면 공도 던져보라 그러고...... 와서 해주는 거는 고맙지, 그럼. 나가지도 못하는데, 와서 이거라도 시키고 공이라도 던지니까" (재활대상자F)

"왜냐면 저 같은 경우는 누구라도 와서 한 번이라도 와서 좀 움직 여 주고 두드려 주고...... 혼자서 못 하니까. 그리고 인제 경험 없는 사 람이 어설프게 만지는 것보다 그래도 전문적인 물리치료 선생님이 와서 만져 주시면...... 그거야 뭐 만족 대 만족이죠" (재활대상자 $\mathrm{H}$ )

\section{(2) 사회적 · 감정적 요소}

평소 타인과의 교류가 적은 대상자들은 서비스를 받으며 치료사에 게 친밀감을 느꼈고, 사회관계망을 형성했다고 하였다. 사회적인 면 에 관한 언급은 나이가 어린 대상자에서 더 자주 나타나는 경향이 있 었다.

"어떻게 운동을 시켜야 될지 모르겠는데 그 방법을 알려주시니까, 그리고 애가 아무래도 혼자 있다 보니까 이렇게 주기적으로 오면 그 시간을 기다리는 거 같고 애가 (치료사 선생님이) 오면 반가워하고" (재활대상자 B 보호자)

"양친 모두가 일을 하는 와중에, 치료라기보다 데리고 놀아주는 것 자체가 집안에도 환자에게도 도움이 되요" (재활대상자 I)

\section{(3) 교육적 요소}

연구대상자들은 자신 혹은 보호대상자에게 맞는 운동 방법을 알게 되어서, 치료사가 없는 시간에도 자발적으로 혹은 보호자의 도움으 
로 운동을 수행할 수 있다는 것에 만족하고 있었다.

"선생님이 하는 대로 운동을 어떻게 해야 하는지를 아니까, 이제 선 생님이 안 계셔도 우리가 어떻게 해야 하는지를 알 수 있으니까...... 어떻게 운동을 시켜야 하는지 모르는데, 그 방법을 알려 주시니까 좋 았고" (재활대상자 B)

"다른 거는 못 하니까 많이 주물러 주라고 (하셨어요). 발목하고 엉 덩이 있는 데랑, 무릎 뒤쪽이 갑자기 1년 사이에 크면서 많이 짧아졌 거든요, 다른 곳은 괜찮은데. 그런 데를 주물러 주면 완전히 치료는 안 돼도 많이 좋아질 거라고 이렇게 해 주라고 가르쳐 주시더라고요" (재활대상자 J보호자)

\section{3) 요구사항}

연구대상자들은 치료적, 교육적, 그리고 행정적 요소 중에 향후 방문 물리치료사업이 보완 및 개선되어야 할 사항이 있다고 언급하였다.

\section{(1) 치료적 요소}

거의 모든 연구대상자가 요구사항으로 꼽았던 것은 치료기간과 시간 의 증가와 지속성이었다. 치료 기간과 시간이 짧아서 효과가 나지 않 는 것 같다고 하였다.

"8주 동안 받고 좋아진 것도 없고, 나빠진 것도 없고. 내가 아프고 힘이 없으니까 좋은지를 잘 몰라..... 8주 동안 했는데, 일주일에 한 번 와요. 그러면 8 주라면 8 번 오잖아요? 8번에 뭐가 더 좋아지고, 그런 게 어디 있어요" (재활대상자 C)

"할 수 있으면 앞으로 조금 더 했으면 좋지. 근데 인제 우리는 끝나 서...... 더 자주였으면....." (재활대상자 $\mathrm{G}$ 보호자)

"너무 기간도 짧고 시간이 얼마 안 되니까..... 서로 파악하다 보면 몇 시간은 지나가고 또 다른 분이 오시고 이러니까 계속적인 그런 서 비스가 안 돼서......" (재활대상자 $\mathrm{H}$ )

개인의 요구를 반영한, 보다 목적적인 치료를 원하는 재활대상자 도 있었다.

"내가 사실은 이 애기를 안 하려고 했는데, 변을 못 닦아요. 그래서 내가 변을 꼭 닦아줘야 돼요..... 언니(여자 물리치료사)한테는 애기 를 안 했는데, 인제 남자분이 와서 (불편 사항에 대해) 애기를 해 주었 더니 그거를 위해서, 이거(뒤처리를 스스로 하는 방법)를 가르쳐 주
더라고요. 그 운동을 하면 이 손이 간대요" (재활대상자 E 보호자)

\section{(2) 교육적 요소}

어떤 보호자는 보호자 자신과 치료사의 영향력을 비교하며 더 많은 운동 교육을 요구하였다. 그리고 다른 대상자는 일상생활 관리를 추 가적으로 해주기를 원했다.

"나는 더 가르쳐 주면 좋은데...... 네, 그냥 더 가르쳐 주면 되는데. 그 분들(물리치료사)이 가르쳐 주면 힘들어도 하잖아요” (재활대상 자E보호자)

"물리치료 말고도 또 관리를 같이 해 주면 좋죠, 건강관리를....... 예를 들면 저같이 폴리를 끼고 있으니까 그런 것에 대한 관리요. 그게 제일 문제거든요" (재활대상자 $\mathrm{H})$

\section{(3) 행정적 요소}

연구대상자들은 병원에 자주 갈 수 없는 사람들이 더 많이 알 수 있 도록 적극적으로 홍보해 주기를 원했다. 다른 연구대상자는 방문재 활 대상자 선정과 치료, 평가의 체계성이 부족하다고 느꼈고, 방문재 활사업이 보다 체계적인 서비스가 될 필요가 있다고 진술했다.

"아니, 많이 알았으면 좋겠어. 많이 알아서 이런 혜택 좀 받았으면 좋겠습니다. 내가 이렇게 해 보니까 진짜 좋긴 좋네. 병원에는 갈 수가 없으니까..... 나이런 게 있는지도 몰랐어"(재활대상자 $\mathrm{G}$ 보호자)

"일차적인 상담을 사회복지사가 하더라도, 구체적인 상담을 할 때 에는 전문가가 이 사람은 이런 서비스가 필요하다는 애기가 됐을 때 이 서비스를 받아야..... 사전 평가를 해서 정말 몸에 맞는 운동치료 를 찾아서 해 줬으면 좋겠어요" (재활대상자 $\mathrm{H}$ )

\section{고 찰}

본 연구는 2013년도부터 국립재활원의 지침 하에 지역사회통합건강 증진사업의 일환으로 진행되고 있는 CBR 모형 기반 방문재활사업을 평가하기 위해 수행되었다. 방문재활서비스를 경험한 5 명의 지역사 회 거주 장애인과 6 명의 보호자는 8 주간의 방문재활서비스에 대해 주관적으로 인식한 목적, 효과, 만족도, 요구사항에 대해 연구자와 심 층면담을 수행하였다. 그 결과 대부분의 연구대상자는 8 주간의 서비 스 기간이 충분한 효과를 느끼기에는 짧은 기간이라고 평가하였다, 그럼에도 불구하고 연구대상자들은 신체적 기능에서뿐 아니라 사회 적•감정적 요소와 교육적 요소에서도 효과와 만족감을 느끼고 있는 
것을 알 수 있었다. 특히, 교육적 요소는 연구대상자가 인식한 방문재 활서비스의 목적과 만족도, 요구사항에서 계속 주요한 범주로 도출 되고 있어, 연구대상자들이 방문재활서비스에서 교육적 요소를 중요 하게 생각하고 있다는 것을 짐작할 수 있었다.

연구대상자들은 방문재활 서비스의 목적이 신체기능의 유지와 개 선을 위한 것뿐 아니라, 자가 재활운동 방법 교육과 일상생활 지도를 위한 것이라고 하였다(Table 2). 이와 같은 의견은 치료사가 실제 수행 한 서비스 내용 중 연구대상자들이 중요하다고 생각하였거나, 혹은 본인들에게 의미가 있다고 판단된 활동들인 것으로 사료된다. 이와 같은 결과를 통해 연구대상자들은 즉각적인 신체기능의 개선이 아 니더라도 지속적으로 재활운동 방법을 학습하는 것이 중요하다고 인지하고 있음을 알 수 있다. 또한 그 밖에 단순하게 일상생활을 관리 해주는 활동도 필요로 하고 있음을 알 수 있다. 하지만, 일상생활 관 리의 경우는 방문간호사나 방문사회복지사 등 타 방문전문인력과 특별히 구분되지 않는 활동영역으로써 방문물리치료사가 제공하는 방문재활서비스의 대표적인 업무영역이라고 하기 어렵다는 면에서, 연구대상자들 중 일부는 방문재활서비스의 제공주체가 물리치료사 임을 인지하고 있지 못한 것을 알수 있다.

방문재활서비스의 신체적 효과 측면에서는, 관절가동범위의 증가 등 신체기능 향상을 경험한 연구대상자도 있었으나, 짧은 서비스 시 간과 기간으로 인해 충분한 효과를 알기 어려웠다는 의견이 많았다. 2014년 국립재활원에서 제시하고 있는 CBR사업 지침에서는 정기관 리 대상자에 대해 분기별 1 회 이상의 서비스를 제공할 것을 가이드하 고 있다. 이와 같은 현 $\mathrm{CBR}$ 사업 지침을 감안하면, 본 연구에서 수행 한 회당 1 시간, 주 1 회, 8 주간의 서비스 기간은 짧다고 할 수 없음에도 불구하고 연구대상자들은 그 효과를 알 수 없는 짧은 시간으로 인식 하고 있었다. 이와 같은 결과로 비추어 볼 때, 분기별 1 회 이상을 최소 한의 서비스 제공 횟수로 가이드하고 있는 현재의 국립재활원 지침 은 장애인이 신체기능 향상 효과를 스스로 체감하기 어려운 형식적 인 활동에 그칠 우려가 있는 것으로 판단된다. 그러나 국가의 제한된 복지예산을 감안했을 때, 이와 같은 국립재활원 지침은 단기간에 전 면적으로 개선되기는 어려울 것으로 보여진다. 현 지침이 가지는 이 와 같은 제한점에 대한 대안으로 방문재활서비스 수급자의 상태에 따라 보건소에서 제공하는 재활서비스의 유형을 다양화하는 방안 을 제안해볼 수 있을 것으로 사료된다. 즉, 각 보건소에서 방문재활서 비스를 적용함에 있어서 수급자 유형을 세분화하여, 재활동기가 높 고, 단기간의 재활서비스로 신체기능이 향상될 가능성이 있은 수급 자에게나마 제한적으로는 집중적인 재활서비스를 제공하여 신체기 능 향상을 도모하는 방법이 필요할 것이다. 혹은 제한된 국가예산에 대한 타개책으로 기초생활수급자 및 차상위계층 이외 대상자에게는 방문재활서비스를 유료화하는 방안도 고려해볼 수 있을 것이다.
방문재활서비스에 대한 사회적·감정적 효과로 치료사에 대한 고 마움, 애정 혹은 미안한 감정 등에 따른 운동 동기유발 효과가 도출되 었다. 이와 같은 결과는 방문재활활동으로 연구대상자와 치료사간 에 유대감이 형성되었음을 짐작하게 하고, 이는 $\bigcirc \bigcirc$ 구의 방문재활 사업이 장애인에게 수용적인 사회 환경 조성과 장애인의 지역사회 참여 등을 목표로 하는 $\mathrm{CBR}$ 의 사회적 모형'에 부합하는 형태로 이루 어졌음을 검증해준다. 특히, 사회적, 감정적 효과는 연구대상자들이 인식하는 방문재활사업의 목적으로 인식한 내용에는 포함되어 있지 않음에 주목할 필요가 있다. 즉, 연구대상자는 방문재활사업의 목적 이 신체기능과 일상생활의 유지 및 향상에 있다고 인지하고 있는 것 은 분명하나, 이번 연구기간을 통해 방문재활서비스의 사회적·감정 적 효과를 새롭게 인지하였음을 알 수 있다. 이와 같은 연구대상자의 경험은 방문재활에 대한 목적이 신체기능의 향상을 넘어 사회참여 를 위한 것이라고 향후 연구대상자가 확장하여 인식할 수 있는 여지 를 보여주고 있다.

만족도에서 특히 주목할 만한 점은 연구대상자들이 '전문가'에 의 한, 움직임을 유도하는 치료에 대해 만족감을 느끼고 있다는 점이다. 잘못된 움직임, 혹은 움직임이 없는 상태에서 올바른 움직임을 가이 드하고, 교육시키는 것은 물리치료사 혹은 작업치료사 고유의 업무 영역이다. ${ }^{22}$ 방문재활서비스 제공자로는 물리치료사 이외에도 방문 간호사, 방문사회복지사 등이 있으나, '움직임을 유도하는 치료'는 물 리치료사 혹은 작업치료사만이 가능하다. 그러므로 이와 같은 연구 대상자의 답변에서 물리치료사나 작업치료사 등 운동재활 전문가에 의한 방문재활서비스는 치료적 요소에 대한 장애인의 만족감을 향 상시킬 수 있을 것임을 짐작할 수 있다.

연구대상자들은 교육적 요소에서도 만족감을 얻고 있었다. 교육 적 요소는 일회적인 치료로 완치되기 어려운 만성 재가장애인이 스 스로 혹은 보호자의 도움을 받아 자가 재활운동을 수행할 수 있도록 치료사가 교육하는 것으로, 장애인이 일상생활에서 보다 독립적인 생활이 가능하도록 지원하는 활동이다. 본 연구 결과로 비추어 보았 을 때 방문재활서비스가 치료를 제공하는 데에만 비중을 두기 보다 는 장애인 스스로 지속적인 관리가 가능하도록 교육적 요소에도 관 심을 가질 필요가 있을 것으로 판단된다. 다만, 현재 보건복지부와 한 국건장증진재단에서 발간한 2013년 지역사회통합건강증진사업 지 침23에 따르면 방문건강관리사업에서 자가관리 훈련은 운동전문인 력'의 역할로 정의되어 있어 논란의 소지가 있다. 즉, 현 지침ㄹㅇㅔ 따르 면, 자가 재활운동 교육은 운동전문인력의 역할로써, 방문물리·작업 치료사의 역할에서는 제외되는 것으로 해석될 소지가 있으나, 이는 잘못된 해석이다. 방문건강관리를 수행하는 주체는 방문물리.작업 치료사와 운동전문인력 외에도 방문간호사, 방문치과위생사, 방문영 양사, 방문사회복지사 등으로 다양하다. ${ }^{23}$ 그리고 모든 방문전문인력 
은 방문재활 시 수행하게 되는 각자의 고유활동 영역과 관련해서 방 문재활대상자에게 교육을 수행할 수 있어야 한다. 또한, 이를 위해서 는 각 방문재활인력간의 업무 영역이 보다 구체적으로 정의될 필요 가 있다. 그러나 2013년 지역사회통합건강증진사업 지침23에는 각 방 문인력의 역할이 단 몇 줄로 간단히 기술되어 있고, 그 중 '자가관리 훈련은 운동전문인력의 역할로만 기술되어 있어 시급한 수정, 보완 작업이 필요한 것으로 판단된다.

방문재활서비스에 대한 대상자들의 추가적인 요구사항으로는 방 문재활서비스의 효과 및 만족도에서 도출된 범주들이 다시 강조되 는 형태로 도출되었다. 즉, 연구대상자들은 짧은 치료시간과 기간으 로 서비스의 효과를 충분히 알 수 없었으므로 더 많은 시간의 지속적 인 서비스를 요구하였고, 방문재활서비스의 목적과 만족도 영역에서 도출되었던 교육적 요소가 다시 한번 요구사항으로 도출되었다. 특 히 연구대상자들은 자가 재활운동 방법 습득을 위해서뿐만 아니라, 일상생활 관리를 위해서도 교육이 필요하다고 언급하고 있어, 병원에 서 치료사가 환자를 치료하는 활동과 방문재활 활동에서 장애인에 게 제공되어야 할 서비스에는 차이가 있어야 한다는 사실을 시사하 고있다.

본 연구는 다음과 같은 제한점을 갖는다. 첫째, 방문재활 대상자의 유형이 다양하여 특정한 장애유형에 대한 심층적인 분석이 진행되 지 않았다. 그러나 이는 지역사회에서 방문재활서비스를 제공하게 되 는 경우 경험하게 되는 일반적인 현상으로 보여진다. 둘째, 보건소 중 심으로 저소득층을 대상으로 진행되는 $\mathrm{CBR}$ 사업의 특성 상 본 연구 에서 방문재활서비스는 연구대상자에게 무료로 제공되었으며, 이와 같은 이유로 인해 연구대상자가 연구자의 질문에 대해 솔직한 견해 를 제시하지 하지 않았을 가능성이 있다. 마지막으로 연구대상자 수 가 적어 충분히 다양한 의견을 분석하는 데에는 한계가 있다. 이와같 은 제한점에도 불구하고, 본 연구의 강점은 방문재활서비스의 수급 자인 장애인을 대상으로 심층면담을 통해 그들의 주관적 경험을 분 석함으로써, 기존의 설문지 방식에 의한 연구보다 심도 있는 분석을 진행하였다는 점이다. 이와 같은 연구 결과는 방문재활대상자 관점 으로 도출된 유용한 정보를 제공함으로써 방문재활사업의 효과를 극대화시킬 수 있을 것으로 판단된다.

8 주간의 방문재활서비스 기간은 충분한 효과를 느끼기에는 짧은 기간이었다. 그럼에도 불구하고 연구대상자들은 지역재활사업에 큰 의미를 두어 지역재활의 중요성이 드러났고, 신체적 기능뿐만 아니라 사회적, 감정적 요소와 교육적 요소에서 효과와 만족감을 느끼고 있 어 다양한 차원에서 만족하고 있음을 알 수 있었다. 특히 교육적 요 소는 연구 참여자의 방문재활에 대한 인식과 만족도, 그리고 요구사 항에서 계속 주요한 범주로 도출되고 있어, 방문재활서비스 중 교육 적 요소를 중요하게 생각해야 할 필요성을 제기하였다. 이와 같은 연
구결과는 2017년 이후부터 본격적으로 $\mathrm{CBR}$ 사업을 수행하게 될 전국 의 CBR사업 주체들이 방문재활 사업을 시작함에 있어서 방문재활 대상자 관점에서 감안해야 할 유용한 정보를 제공할 수 있을 것으로 사료된다.

\section{REFERENCES}

1. Ministry of Health and Welfare. The actual condition of the disabilities. 2011.

2. Word Health Organization. Community-based rehabilitation guidelines. 2010.

3. National Rehabilitation Center. Guideline for the community-based integrated health promotion program. 2013.

4. Kim M. The study of efficient way of home-based physical therapy. Sahmyook University. Dissertation of Doctoral Degree. 2011.

5. Kim HJ. A study for the introduction of home rehabilitation services in long-term care insurance system for the elderly. Inje University. Dissertation of Doctoral Degree. 2010.

6. Yang YA, An SJ, Park YH, et al. A study of visiting Rehabilitation service and implementation method. KAPA. 2011;3(1):59-70.

7. Yoon TH. A study of the inclusion of home-based physical therapy services in the long-term care insurance. Hanyang University. Dissertation of Doctoral Degree. 2009.

8. Park SK, Heo JW, Yang DJ, et al. Effects of home visiting physical therapy and environmental factors analysis using international classification of functioning, disability and health (ICF). J Kor Phys Ther. 2012;24(4): 282-89.

9. Park SK, Ji HY, Heo JW. Effects of home visiting physical therapy on activities of daily living and function in disabled persons living at home. J Kor Phys Ther. 2011;23(2):61-8.

10. Kim SM, Song JM. The efficacy of community-based rehabilitation exercise to improve physical function in old women with knee arthritis. J Kor Phys Ther. 2010;22(1):9-17.

11. An D. Effects on improvement of activities of daily living through shortterm home visiting physical therapy. Phys Ther Kor. 2007;14(2):53-60.

12. Yoon TY, Kim HR, Park RJ. A survey on home care team's perception in health center about home-based physical therapy among home care service for long term care insurance. KPTSA. 2009;16(3):43-53.

13. Lee MS, Kim MC, Kim GY. A study for home-based physical therapy service introduction through a group of professionals in-depth interview. J Korean Soc Phys Med. 2013;8(3):303-15.

14. Kwon HJ, Hwang SS. A review on the needs and understanding about the home physical therapy system. KOHAC. 2005;2(2):83-99.

15. Son KH, Kim EK, Kim SM. Research about necessity of visiting home physical therapy. KPTSA. 2012;19(1):27-38.

16. Choi S, Yoon J. Awareness and demand for pediatric home-based physical therapy in Korea. Phys Ther Kor. 2013;20(3):62-73.

17. Jang MS. Needs for activation of community based rehabilitation (CBR): qualitative study and questionnaire survey. Inje University. Dissertation of Doctoral Degree. 2013.

18. Yi C, Weon J, Ok J. House visits by physical therapist and patient needs. Phys Ther Kor. 2000;7(1):64-78. 
19. Ahn CS, Yu WJ. A study of management and satisfaction for home visiting physical therapy. J Korean Soc Phys Med. 2012;7(3):241-50.

20. Junggu office. Current situation of registration of each type of the disabilities. 2013.

21. Krefting L. Rigor in qualitative research: the assessment of trustworthi- ness. Am J Occup Ther. 1991;45(3):214-22.

22. Medical technicians, etc. act. Ministry of health and welfare, 2011.

23. Korea Health Promotion Foundation. Guideline for home visiting health service. 2013. 